\title{
Effect of Foliar Applied Tryptophan on Tuberose Plants for Decreasing the Harmful Effect of Some Heavy Metals Pollution in the Irrigation Water (A) Effect of Cadmium Treatments
}

\author{
Nader A. El-Shanhorey ${ }^{1}$ and Samira S. Ahmed ${ }^{2}$ \\ ${ }^{1}$ Botanical Gardens Research Department, Horticultural Research Institute, ARC, Alexandria, Egypt. \\ ${ }^{2}$ Botanical Gardens Research Department, Horticulture Research Institute, ARC, Geza, Egypt.
}

\begin{abstract}
The present study was carried-out at Antoniadis Research Branch, Horticultural Research Institute, Agriculture Research Center (ARC), Alexandria, Egypt during two successive seasons of 2018 and 2019. The aim of this study was to evaluate the effects of irrigation water contaminated with cadmium on the growth of Polianthes tuberosa plants and the possibility of using tryptophan spray treatments to overcome the effects of cadmium pollution. Corms of Polianthes tuberosa were planted individually in plastic pots $(20 \mathrm{~cm}$ diameter $)$ filled with $5 \mathrm{~kg}$ of sandy soil. The Cadmium contaminated irrigation water treatments were $0,100,200$ and $300 \mathrm{mg} / \mathrm{L}$ were applied. The plants were also monthly sprayed by tryptophan at concentrations of 0,250 and $500 \mathrm{mg} / \mathrm{L}$.

The results showed that for vegetative growth parameters there was no significant difference in the interaction between cadmium polluted water of irrigation and foliar spray by tryptophan, while a significant reduction was observed in all parameters after irrigation with cadmium polluted water and a significant increase in vegetative growth parameters was observed after $500 \mathrm{mg} / \mathrm{L}$ tryptophan application. For chlorophyll and carbohydrate content, the highest significant value was obtained in plants irrigated with tap water and sprayed with $250 \mathrm{mg} / \mathrm{L}$ tryptophan while the highest significant level of cadmium content in leaves and corms was obtained due treatment by $300 \mathrm{mg} / \mathrm{L}$ cadmium without application of tryptophan.
\end{abstract}

Key words: Polianthes tuberose, cadmium, tryptophan.

\section{INTRODUCTION}

Tuberose (Polianthes tuberosa L.), a member of the Agavaceae family native to Mexico, has long been cherished for the aromatic oils extracted from its fragrant white flowers (Trueblood, 1973). It has recently gained popularity as a cut flower and in number of countries including Kenya, India and Mexico it is grown commercially for export to the USA, Europe and Japan. Tuberose inflorescences (spikes) bear 10-20 pairs of florets which open acropetally. Commercially, spikes $60-90 \mathrm{~cm}$ long are harvested when two or three of the basal florets are open. Less than $50 \%$ of the buds normally open after harvest and florets and buds usually abscond after only few days in the vase. Postharvest performance is worse in tuberose which has been shipped to distant markets. Since tuberose originated from the sub-tropics, this loss of quality might be due to chilling injury induced by exposure to low but non-freezing temperatures during marketing. Alternatively, it might be the result of postharvest desiccation, or improper temperature management.

Ramaih et al. (2003) confirmed that tryptophan is the major precursor of Indol Acitic Acid (IAA) in most organisms. Plants produce IAA from tryptophan through indole-3-pyruvic acid (Mashiguchi et al., 2011) and (Won, 2011). IAA is also produced from tryptophan through indole-3acetaldoxime in Arabidopsis (Satoko et al., 2009). El-Bassiouny (2005) demonstrated that tryptophan and nicotinamide increased IAA, Geberellic acid (GA3), cytokinens, and decreased abscicic acid (ABA) in wheat. Nicotinamide is a stress induced compound to provide defense mechanism against a specific stress. Wyszkowska (1999) and ElBassiouny (2005) observed an increase in some minerals $\mathrm{K}^{+}, \mathrm{Ca}^{2+}$ and $\mathrm{Mg}^{2+}$ in wheat plant tissues by tryptophan treatment.

In this study Polianthes tuberosa was selected due to its characteristics as non-edible plant, cut flowers and it has many uses in landscaping, therefore the objective of this study is to determine the potential of Polianthes tuberosa in removing heavy metals from the soil affected with contaminated irrigation water and to investigate the ability of Polianthes tuberosa in removing heavy metals.

\section{MATERIALS AND METHODS}

The present study was carried-out at Antoniadis Research Branch, Horticultural Research Institute, Agriculture Research Center (ARC), Alexandria, Egypt during the two successive seasons of 2018 and 2019, respectively.

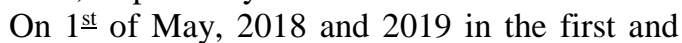
second seasons, respectively, Tuberose (Polianthes tuberosa, L. cv. "Double") corms with average diameter of $3.8 \mathrm{~cm}$ and $70.0 \mathrm{~g}$ fresh weight were obtained from a commercial nursery in Alexandria and planted individually in plastic pots $(20 \mathrm{~cm}$ diameter) filled with $5 \mathrm{~kg}$ of sandy soil. The chemical constituents of the soil were measured as 
described by Jackson (1958) and the results obtained are shown in Table (1).

On $15^{\text {th }}$ of May (in both seasons), the contaminated irrigation water treatments were initiated. Four concentrations of cadmium acetate [Cd $\left.\left(\mathrm{CH}_{3} \mathrm{COO}\right)_{2} 2 \mathrm{H}_{2} \mathrm{O}\right] \quad 0,100,200$ and $300 \mathrm{mg} / \mathrm{L}$ were applied. The plants were irrigated three times per week; at the end of the experiment every plant received about (120) liters per pot of contaminated water in Table (2). In both seasons, the plants were received by monthly spraying from $15^{\text {th }}$ June till $15^{\text {th }}$ September in both seasons. The plants were also sprayed with tryptophan at concentrations of 0,250 and $500 \mathrm{mg} / \mathrm{L}$. Control plants were sprayed with tap water. On $30^{\text {th }}$ of October in the both seasons, the plants were harvested.

In both seasons, all plants received NPK chemical fertilization using fertilizer (Milagro Aminoleaf 20-20-20) at the rate of $3 \mathrm{~g} /$ pot. Fertilization was repeated every 30 days throughout the growing season (from $20^{\text {th }}$ of May till $20^{\text {th }}$ of October). In addition, weeds were removed manually upon emergence.

\section{Data recorded:}

\section{(1) Vegetative growth parameters:}

Plant height $(\mathrm{cm})$, number of leaves per plant, leaves dry weight per plant $(\mathrm{g})$, leaves area $\left(\mathrm{cm}^{2}\right)$ according to Koller (1972), flower number per spike, flower dry weight (g), spike dry weight (g), rachis length $(\mathrm{cm})$, corm diameter $(\mathrm{cm})$, corm dry weight $(\mathrm{g})$ and number new cormlets were also measured.

(2) Chemical analysis determination:

- Total chlorophyll content was determined as a SPAD from the fresh leaves of plants for the different treatments under the experiment at the end of the season using Minolta (chlorophyll meter) SPAD 502 according to Yadava (1986).

- Total carbohydrate percentage in the leaves was determined according to Dubios et al.(1956).

- Proline content (mg/g) in the leaves was determined according to Bates et al. (1973).

- Determination of cadmium content. Plant samples were divided into leaves stem and roots. They were then dried at $72^{\circ} \mathrm{C}$ in an oven until completely dried. The dried plant samples were ground to powder. The dried samples were then digested for extraction of cadmium, using the method described by Piper (1947) method and the concentration of heavy metal was determined using an atomic absorption spectrophotometer.

- Available cadmium in soil samples were extracted by DPTA solution according to Lindsay and Norvell (1978) and determined by Inductively Coupled Plasma Spectrometry.
- Transfer factor (TF) is given by the relation: the ratio of the concentration of metal in the shoots to the concentration of metal in the soil (Chen et al., 2004). Indicates to the efficiency of any plant to transfer any metal from soil to the aerial parts.

The experimental design was split plot with three replicates. Each replicate contained three plants. The main plot was cadmium polluted water concentration, while the subplot was tryptophan treatments. Data were subjected to analysis of variance (ANOVA) using the SAS program, SAS Institute (SAS Institute, 2002). The Means of the individual factors and their interactions were compared by L.S.D test at 5\% level of probability according to Snedecor and Cochran (1989).

\section{RESULTS}

\subsection{Vegetative growth:}

\subsubsection{Leaves parameters}

Data presented in Table (3) Showed that, in both seasons, irrigation water polluted with cadmium decreased the leaves parameters of Polianthes tuberosa plants. Plants irrigated with tap water (control) had the highest mean values of plant height $(92.62$ and $93.51 \mathrm{~cm})$, number of leaves per plant (90.53 and 91.42), leaves dry weight (22.01 and $22.23 \mathrm{~g}$ ) and leaves area (1296.70 and 1309.28 $\mathrm{cm}^{2}$ ) in the first and second seasons, respectively. Moreover, raising the cadmium concentration caused steady significant reductions in leaves parameters, with the highest concentration (300 $\mathrm{mg} / \mathrm{L}$ ) giving significantly the shortest plants mean values of plant height (76.31 and $78.55 \mathrm{~cm}$ ), number of leaves per plant (74.22 and 76.46), leaves dry weight (18.05 and $18.59 \mathrm{~g})$ and leaves area (1068.43 and $\left.1099.74 \mathrm{~cm}^{2}\right)$ in the first and second seasons, respectively.

Leaves parameters was also significantly affected by spraying the plants with tryptophan. In both seasons, leaves parameters increased gradually when the tryptophan concentration was raised from $0 \mathrm{mg} / \mathrm{L}$ (control) to $500 \mathrm{mg} / \mathrm{L}$. Accordingly, it can be seen from the data in Table (3) that Polianthes tuberosa plants sprayed with $500 \mathrm{mg} / \mathrm{L}$ tryptophan were significantly mean values of plant height (84.43 and $85.59 \mathrm{~cm})$, number of leaves per plant (82.34 and 83.50), leaves dry weight (20.02 and $20.30 \mathrm{~g})$ and leaves area $\left(1182.08\right.$ and $\left.1198.29 \mathrm{~cm}^{2}\right)$ in the first and second seasons, respectively.

Regarding the interaction between of irrigation with cadmium polluted water and tryptophan treatments on leaves parameter of Polianthes tuberosa plants, the results recorded in the two seasons show that, the highest values were obtained in the plants irrigated with tap water (control) and sprayed with tryptophan at $500 \mathrm{mg} / \mathrm{L}$ with mean values of plant height (94.72 and $95.52 \mathrm{~cm}$ ), 
Table 1: The chemical properties of the used sandy soil for the two successive seasons 2018 and 2019.

\begin{tabular}{|c|c|c|c|c|c|c|c|c|c|}
\hline \multirow{2}{*}{ Season } & \multirow[t]{2}{*}{ pH } & \multirow{2}{*}{$\begin{array}{c}\text { EC } \\
\text { ds } / \mathbf{m}\end{array}$} & \multicolumn{4}{|c|}{ Cations (meq/l) } & \multicolumn{3}{|c|}{ Anions (meq/l) } \\
\hline & & & $\mathbf{C a}^{++}$ & $\mathbf{M g}^{++}$ & $\mathrm{Na}^{+}$ & $\mathbf{K}^{+}$ & $\mathrm{HCO}_{3}^{-}$ & $\mathrm{Cl}^{-}$ & $\mathrm{SO}_{4}^{--}$ \\
\hline 2018 & 7.93 & 1.55 & 4.4 & 3.6 & 6.5 & 1.3 & 3.6 & 6.7 & 2.4 \\
\hline 2019 & 7.91 & 1.52 & 4.2 & 3.1 & 6.3 & 1.2 & 3.3 & 6.5 & 2.2 \\
\hline
\end{tabular}

Table 2: Total amount of the water used for each plant (1/pot) in each treatment during the growing two seasons of 2018 and 2019.

\begin{tabular}{lccccccc}
\hline \multirow{2}{*}{ Field Capacity $(\%)$} & \multicolumn{7}{c}{ Months of first and second seasons } \\
\cline { 2 - 8 } & May & June & July & August & September & October & Total \\
\hline $100 \%$ & 17.00 & 18.00 & 20.00 & 23.00 & 22.00 & 20.00 & 120.00 \\
\hline
\end{tabular}

Table 3: Means of plant height (cm), number of leaves per plant, leaves dry weight (g) and leaves area $\left(\mathrm{cm}^{2}\right)$ of Polianthes tuberosa plants as influenced by cadmium $(\mathrm{Cd})$, tryptophan $(\mathrm{T})$ and their combinations $(\mathrm{Cd} \times \mathrm{T})$ in the two seasons of 2018 and 2019 .

\begin{tabular}{|c|c|c|c|c|c|c|c|c|c|}
\hline \multirow{2}{*}{$\begin{array}{l}\text { Treatments } \\
\begin{array}{l}\text { Cadmium } \\
(\mathrm{mg} / \mathrm{L})\end{array}\end{array}$} & \multirow[b]{2}{*}{$\begin{array}{l}\text { Tryptophan } \\
\text { (mg/L) }\end{array}$} & \multicolumn{2}{|c|}{$\begin{array}{c}\text { Plant height } \\
(\mathrm{cm})\end{array}$} & \multicolumn{2}{|c|}{$\begin{array}{c}\text { Number of } \\
\text { leaves per plant }\end{array}$} & \multicolumn{2}{|c|}{$\begin{array}{c}\text { Leaves dry } \\
\text { weight (g) }\end{array}$} & \multicolumn{2}{|c|}{$\begin{array}{c}\text { Leaves area } \\
\left(\mathrm{cm}^{2}\right)\end{array}$} \\
\hline & & 2018 & 2019 & 2018 & 2019 & 2018 & 2019 & 2018 & 2019 \\
\hline \multirow{3}{*}{0} & 0 & 90.42 & 91.18 & 88.33 & 89.09 & 21.48 & 21.67 & 1265.88 & 1276.61 \\
\hline & 250 & 92.72 & 93.85 & 90.63 & 91.76 & 22.04 & 22.32 & 1298.12 & 1313.95 \\
\hline & 500 & 94.72 & 95.52 & 92.63 & 93.43 & 22.53 & 22.72 & 1326.12 & 1337.28 \\
\hline Mean $(\mathrm{Cd})$ & & 92.62 & 93.51 & 90.53 & 91.42 & 22.01 & 22.23 & 1296.70 & 1309.28 \\
\hline \multirow{3}{*}{100} & 0 & 82.62 & 83.74 & 80.53 & 81.65 & 19.58 & 19.86 & 1156.68 & 1172.36 \\
\hline & 250 & 83.83 & 84.30 & 81.74 & 82.21 & 19.88 & 19.99 & 1173.71 & 1180.20 \\
\hline & 500 & 86.49 & 86.63 & 84.40 & 84.54 & 20.53 & 20.56 & 1210.95 & 1212.83 \\
\hline Mean $(\mathrm{Cd})$ & & 84.31 & 84.89 & 82.22 & 82.80 & 19.99 & 20.13 & 1180.44 & 1188.46 \\
\hline \multirow{3}{*}{200} & 0 & 76.39 & 78.96 & 74.30 & 76.87 & 18.07 & 18.69 & 1069.50 & 1105.49 \\
\hline & 250 & 78.84 & 80.85 & 76.75 & 78.76 & 18.67 & 19.15 & 1103.76 & 1131.95 \\
\hline & 500 & 80.05 & 81.52 & 77.96 & 79.43 & 18.96 & 19.32 & 1120.79 & 1141.28 \\
\hline Mean $(\mathrm{Cd})$ & & 78.42 & 80.44 & 76.33 & 78.35 & 18.56 & 19.05 & 1098.01 & 1126.24 \\
\hline \multirow{3}{*}{300} & 0 & 76.18 & 78.41 & 74.09 & 76.32 & 18.02 & 18.56 & 1066.52 & 1097.74 \\
\hline & 250 & 76.30 & 78.55 & 74.21 & 76.46 & 18.05 & 18.60 & 1068.29 & 1099.70 \\
\hline & 500 & 76.46 & 78.70 & 74.37 & 76.61 & 18.09 & 18.63 & 1070.48 & 1101.80 \\
\hline Mean $(\mathrm{Cd})$ & & 76.31 & 78.55 & 74.22 & 76.46 & 18.05 & 18.59 & 1068.43 & 1099.74 \\
\hline \multirow{3}{*}{ Mean $(\mathrm{T})$} & 0 & 81.40 & 83.07 & 79.31 & 80.98 & 19.28 & 19.69 & 1139.64 & 1163.05 \\
\hline & 250 & 82.92 & 84.38 & 80.83 & 82.29 & 19.66 & 20.01 & 1160.97 & 1181.45 \\
\hline & 500 & 84.43 & 85.59 & 82.34 & 83.50 & 20.02 & 20.30 & 1182.08 & 1198.29 \\
\hline \multirow{3}{*}{$\begin{array}{l}\text { L.S.D. at } \\
0.05\end{array}$} & $\mathrm{Cd}$ & 1.46 & 1.61 & 1.46 & 1.61 & 0.35 & 0.39 & 20.48 & 22.56 \\
\hline & $\mathrm{T}$ & 0.78 & 0.67 & 0.78 & 0.67 & 0.19 & 0.11 & 10.99 & 9.41 \\
\hline & $\mathrm{Cd} * \mathrm{~T}$ & 0.90 & 0.77 & 0.90 & 0.77 & 0.22 & 0.18 & 12.63 & 10.81 \\
\hline
\end{tabular}

number of leaves per plant (92.63 and 93.43), leaves dry weight (22.53 and $22.72 \mathrm{~g}$ ) and leaves area (1326.12 and $1337.28 \mathrm{~cm}^{2}$ ) in the first and second seasons, respectively. On the other hand, the shortest plants with mean values of plant height (76.18 and $78.41 \mathrm{~cm}$ ), number of leaves per plant (74.09 and 76.32), leaves dry weight (18.02 and $18.56 \mathrm{~g})$ and leaves area (1066.52 and $\left.1097.74 \mathrm{~cm}^{2}\right)$ in the first and second seasons, respectively, were resulted when the plants were irrigated using the highest cadmium concentration $(300 \mathrm{mg} / \mathrm{L})$ without tryptophan treatment. It can also been seen from the data presented in Table (3) that in many cases, spraying the plants with tryptophan reduced the undesirable effect of contaminated water with cadmium.

\subsubsection{Flowering parameters}

Data presented in Table (4) showed that, in both seasons, irrigation water polluted with cadmium decreased the flowering parameters of Polianthes tuberosa plants. Plants irrigated with tap water (control) had the highest mean values of number of flower number per spike (25.65 and 25.89), flower dry weight (6.20 and $6.26 \mathrm{~g})$, spike dry weight (7.82 and $7.88 \mathrm{~g}$ ) and rachis length (23.72 and $23.93 \mathrm{~cm}$ ) in the first and second seasons, respectively. Moreover, raising the cadmium concentration caused steady significant reductions in flowering 
parameter, with the highest concentration (300 $\mathrm{mg} / \mathrm{L})$ giving significantly the smallest flowers mean values of number of flowers per spike (21.13 and 21.75), flower dry weight (5.11 and $5.26 \mathrm{~g}$ ), spike dry weight (6.73 and $6.88 \mathrm{~g})$ and rachis length $(19.93$ and $20.45 \mathrm{~cm})$ in the first and second seasons, respectively.

Flowering parameters was also significantly affected by spraying the plants with tryptophan. In both seasons, plant height increased gradually when the tryptophan concentration was raised from 0 $\mathrm{mg} / \mathrm{L}$ (control) to $500 \mathrm{mg} / \mathrm{L}$. Accordingly, it can be seen from the data in Table (4) that Polianthes tuberosa plants sprayed with $500 \mathrm{mg} / \mathrm{L}$ tryptophan were significantly mean values of number of flowers per spike (23.38 and 23.70), flower dry weight (5.65 and $5.73 \mathrm{~g})$, spike dry weight (7.28 and $7.35 \mathrm{~g})$ and rachis length $(21.82$ and $22.09 \mathrm{~cm})$ in the first and second seasons, respectively.

Regarding the interaction between of irrigation with cadmium polluted water and tryptophan treatments on flowering parameters of Polianthes tuberosa plants, the results recorded in the two seasons showed that, the highest values were obtained in the plants irrigated with tap water and sprayed with tryptophan at $500 \mathrm{mg} / \mathrm{L}$ with mean values of number of flowers per spike (26.23 and
26.45), flower dry weight (6.34 and $6.40 \mathrm{~g})$, spike dry weight (7.98 and $8.02 \mathrm{~g}$ ) and rachis length $(24.21$ and $24.39 \mathrm{~cm})$ in the first and second seasons, respectively. On the other hand, the smallest plants with mean values of number of flowers per spike (21.09 and 21.71), flower dry weight (5.10 and $5.25 \mathrm{~g})$, spike dry weight (6.72 and $6.87 \mathrm{~g})$ and rachis length (19.90 and $20.42 \mathrm{~cm})$ in the first and second seasons, respectively, were resulted in when the plants were irrigated using the highest cadmium concentration $(300 \mathrm{mg} / \mathrm{L})$ without tryptophan treatment. It can also been seen from the data presented in Table (4) that in many cases, spraying the plants with tryptophan reduced the undesirable effect of polluted water with cadmium.

\subsubsection{Corm parameters}

The data recorded for the corm parameters of Polianthes tuberosa plants in the two seasons Table (5) showed that irrigation with cadmium polluted water decreased corm parameter, compared to that of plants irrigated with tap water (control). In both seasons, plants irrigated with tap water had the thickest corm, with mean corm diameter (5.50 and $5.56 \mathrm{~cm}$ ), corm dry weight (33.02 and $33.35 \mathrm{~g}$ ) and number new cormlets (14.67 and 14.81) in the first and second seasons, respectively.

Table 4: Means of flower number per spike, flower dry weight (g), spike dry weight (g) and rachis length (cm) of Polianthes tuberosa plants as influenced by cadmium $(\mathrm{Cd})$, tryptophan $(\mathrm{T})$ and their combinations $(\mathrm{Cd} \times \mathrm{T})$ in the two seasons of 2018 and 2019 .

\begin{tabular}{|c|c|c|c|c|c|c|c|c|c|}
\hline \multirow{2}{*}{$\begin{array}{l}\text { Treatments } \\
\text { Cadmium } \\
(\mathrm{mg} / \mathrm{L})\end{array}$} & \multirow[b]{2}{*}{$\begin{array}{l}\text { Tryptophan } \\
\text { (mg/L) }\end{array}$} & \multicolumn{2}{|c|}{$\begin{array}{c}\text { Flower number } \\
\text { per spike }\end{array}$} & \multicolumn{2}{|c|}{$\begin{array}{c}\text { Flower dry } \\
\text { weight (g) }\end{array}$} & \multicolumn{2}{|c|}{$\begin{array}{l}\text { Spike dry } \\
\text { weight (g) }\end{array}$} & \multicolumn{2}{|c|}{$\begin{array}{c}\text { Rachis length } \\
\text { (cm) }\end{array}$} \\
\hline & & 2018 & 2019 & 2018 & 2019 & 2018 & 2019 & 2018 & 2019 \\
\hline \multirow{3}{*}{000} & 0 & 25.04 & 25.25 & 6.05 & 6.11 & 7.67 & 7.73 & 23.21 & 23.39 \\
\hline & 250 & 25.68 & 25.99 & 6.21 & 6.29 & 7.83 & 7.91 & 23.74 & 24.01 \\
\hline & 500 & 26.23 & 26.45 & 6.34 & 6.40 & 7.98 & 8.02 & 24.21 & 24.39 \\
\hline Mean $(\mathrm{Cd})$ & & 25.65 & 25.89 & 6.20 & 6.26 & 7.82 & 7.88 & 23.72 & 23.93 \\
\hline \multirow{3}{*}{100} & 0 & 22.88 & 23.19 & 5.53 & 5.61 & 7.15 & 7.23 & 21.40 & 21.66 \\
\hline & 250 & 23.21 & 23.34 & 5.61 & 5.64 & 7.23 & 7.26 & 21.68 & 21.79 \\
\hline & 500 & 23.95 & 23.99 & 5.79 & 5.80 & 7.42 & 7.42 & 22.30 & 22.33 \\
\hline Mean $(\mathrm{Cd})$ & & 23.34 & 23.50 & 5.64 & 5.68 & 7.26 & 7.30 & 21.79 & 21.92 \\
\hline \multirow{3}{*}{200} & 0 & 21.15 & 21.87 & 5.11 & 5.29 & 6.74 & 6.91 & 19.96 & 20.55 \\
\hline & 250 & 21.83 & 22.39 & 5.28 & 5.42 & 6.90 & 7.04 & 20.53 & 20.99 \\
\hline & 500 & 22.17 & 22.57 & 5.36 & 5.46 & 6.98 & 7.09 & 20.81 & 21.15 \\
\hline Mean $(\mathrm{Cd})$ & & 21.71 & 22.27 & 5.25 & 5.39 & 6.87 & 7.01 & 20.43 & 20.89 \\
\hline \multirow{3}{*}{300} & 0 & 21.09 & 21.71 & 5.10 & 5.25 & 6.72 & 6.87 & 19.90 & 20.42 \\
\hline & 250 & 21.13 & 21.75 & 5.11 & 5.26 & 6.73 & 6.88 & 19.93 & 20.46 \\
\hline & 500 & 21.19 & 21.79 & 5.12 & 5.27 & 6.75 & 6.89 & 19.97 & 20.49 \\
\hline Mean $(\mathrm{Cd})$ & & 21.13 & 21.75 & 5.11 & 5.26 & 6.73 & 6.88 & 19.93 & 20.45 \\
\hline \multirow{3}{*}{ Mean $(\mathrm{T})$} & 0 & 22.54 & 23.00 & 5.44 & 5.56 & 7.07 & 7.18 & 21.11 & 21.50 \\
\hline & 250 & 22.96 & 23.36 & 5.55 & 5.65 & 7.17 & 7.27 & 21.47 & 21.81 \\
\hline & 500 & 23.38 & 23.70 & 5.65 & 5.73 & 7.28 & 7.35 & 21.82 & 22.09 \\
\hline \multirow{3}{*}{ L.S.D. at 0.05} & $\mathrm{Cd}$ & 0.40 & 0.44 & 0.09 & 0.11 & 0.10 & 0.11 & 0.34 & 0.37 \\
\hline & $\mathrm{T}$ & 0.21 & 0.18 & 0.05 & 0.04 & 0.05 & 0.04 & 0.18 & 0.15 \\
\hline & $\mathrm{Cd} * \mathrm{~T}$ & 0.24 & 0.21 & 0.06 & 0.05 & 0.06 & 0.05 & 0.20 & 0.17 \\
\hline
\end{tabular}


Table 5: Means of corm diameter (cm), corm dry weight (g) and number new cormlets of Polianthes tuberosa plants as influenced by cadmium $(\mathrm{Cd})$, tryptophan $(\mathrm{T})$ and their combinations $(\mathrm{Cd} \times \mathrm{T})$ in the two seasons of 2018 and 2019.

\begin{tabular}{|c|c|c|c|c|c|c|c|}
\hline \multirow{2}{*}{$\begin{array}{l}\text { Treatments } \\
\begin{array}{l}\text { Cadmium } \\
(\mathrm{mg} / \mathrm{L})\end{array} \\
\end{array}$} & \multirow[b]{2}{*}{$\begin{array}{l}\text { Tryptophan } \\
(\mathrm{mg} / \mathrm{L})\end{array}$} & \multicolumn{2}{|c|}{$\begin{array}{c}\text { Corm diameter } \\
(\mathrm{cm})\end{array}$} & \multicolumn{2}{|c|}{$\begin{array}{c}\text { Corm dry weight } \\
\text { (g) }\end{array}$} & \multicolumn{2}{|c|}{$\begin{array}{c}\text { Number new } \\
\text { cormlets }\end{array}$} \\
\hline & & 2018 & 2019 & 2018 & 2019 & 2018 & 2019 \\
\hline \multirow{3}{*}{000} & 0 & 5.36 & 5.41 & 32.22 & 32.50 & 14.32 & 14.42 \\
\hline & 250 & 5.50 & 5.59 & 33.06 & 33.49 & 14.69 & 14.87 \\
\hline & 500 & 5.64 & 5.68 & 33.80 & 34.08 & 15.02 & 15.15 \\
\hline Mean $(\mathrm{Cd})$ & & 5.50 & 5.56 & 33.02 & 33.35 & 14.67 & 14.81 \\
\hline \multirow{3}{*}{100} & 0 & 4.89 & 4.96 & 29.38 & 29.78 & 13.05 & 13.23 \\
\hline & 250 & 4.97 & 4.99 & 29.82 & 29.99 & 13.25 & 13.32 \\
\hline & 500 & 5.13 & 5.13 & 30.79 & 30.84 & 13.68 & 13.71 \\
\hline Mean $(\mathrm{Cd})$ & & 4.99 & 5.02 & 29.99 & 30.20 & 13.32 & 13.42 \\
\hline \multirow{3}{*}{200} & 0 & 4.51 & 4.66 & 27.12 & 28.04 & 12.04 & 12.46 \\
\hline & 250 & 4.66 & 4.78 & 28.01 & 28.73 & 12.44 & 12.76 \\
\hline & 500 & 4.73 & 4.83 & 28.44 & 28.99 & 12.64 & 12.87 \\
\hline Mean $(\mathrm{Cd})$ & & 4.63 & 4.75 & 27.85 & 28.58 & 12.37 & 12.69 \\
\hline \multirow{3}{*}{300} & 0 & 4.50 & 4.63 & 27.03 & 27.84 & 12.01 & 12.37 \\
\hline & 250 & 4.51 & 4.64 & 27.07 & 27.89 & 12.03 & 12.39 \\
\hline & 500 & 4.52 & 4.65 & 27.13 & 27.95 & 12.05 & 12.42 \\
\hline Mean $(\mathrm{Cd})$ & & 4.51 & 4.64 & 27.07 & 27.89 & 12.03 & 12.39 \\
\hline \multirow{3}{*}{ Mean $(\mathrm{T})$} & 0 & 4.81 & 4.91 & 28.93 & 29.54 & 12.85 & 13.12 \\
\hline & 250 & 4.91 & 5.00 & 29.49 & 30.02 & 13.10 & 13.33 \\
\hline & 500 & 5.00 & 5.07 & 30.04 & 30.46 & 13.34 & 13.53 \\
\hline \multirow{3}{*}{ L.S.D. at 0.05} & $\mathrm{Cd}$ & 0.08 & 0.09 & 0.53 & 0.58 & 0.23 & 0.26 \\
\hline & $\mathrm{T}$ & 0.04 & 0.03 & 0.29 & 0.24 & 0.12 & 0.10 \\
\hline & $\mathrm{Cd} * \mathrm{~T}$ & 0.05 & 0.04 & 0.33 & 0.27 & 0.14 & 0.12 \\
\hline
\end{tabular}

Raising the cadmium concentration in irrigation water caused a steady reduction in corm parameter. This reduction in corm parameter was significant (compared to the control), even at the highest cadmium concentration $(300 \mathrm{mg} / \mathrm{L})$, which gave corm diameter $(4.51$ and $4.64 \mathrm{~cm})$, corm dry weight $(27.07$ and $27.89 \mathrm{~g})$, and number new cormlets (12.03 and 12.39) in the first and second seasons, respectively.

In contrast to the effect of cadmium treatments, tryptophan treatments improved corm parameters of Polianthes tuberosa plants, compared to the control. Moreover, plants sprayed with $500 \mathrm{mg} / \mathrm{L}$ tryptophan had significantly mean corm diameter (5.00 and $5.07 \mathrm{~cm}$ ), corm dry weight (30.04 and $30.46 \mathrm{~g}$ ), and number new cormlets (13.34 and 13.53) in the first and second seasons, respectively.

Regarding the interaction between of irrigation with cadmium polluted water and tryptophan treatments on corm parameter of Polianthes tuberosa plants, the results recorded for the two seasons Table (5) showed that significant differences were detected between the values obtained from plants receiving the different treatment combinations. The highest values mean corm diameter $(5.64$ and $5.68 \mathrm{~cm})$, corm dry weight
(33.80 and $34.08 \mathrm{~g}$ ), and number new cormlets (15.02 and 15.15) in the first and second seasons, respectively, were obtained in the plants irrigated with tap water and sprayed with tryptophan at 500 $\mathrm{mg} / \mathrm{L}$. On the other hand, the thinnest values mean corm diameter $(4.50$ and $4.63 \mathrm{~cm}$ ), corm dry weight (27.03 and $27.84 \mathrm{~g}$ ), and number new cormlets (12.01 and 12.37) in the first and second seasons, respectively, were obtained in the plants irrigated using the highest cadmium concentration $300 \mathrm{mg} / \mathrm{L}$ without tryptophan treatment. It can also been seen from the data presented in Table (5) that in many cases, spraying the plants with tryptophan reduced the undesirable effect of contaminated water with cadmium.

\subsection{Chemical constituents}

\subsubsection{Plant chemical analysis}

The results presented in Table (6) showed that the highest content of total chlorophyll was obtained in plant irrigated with tap water (43.07 and 43.49 SPAD) and total carbohydrate (23.05 and 24.28\%) in the first and second seasons, respectively, while highest proline content (2.51 and $2.47 \mathrm{mg} / \mathrm{g}$ ) were obtained in the plants irrigated with cadmium water at $300 \mathrm{mg} / \mathrm{L}$. Raising the cadmium concentration in irrigation water resulted in steady significant 
reductions in the total chlorophyll and carbohydrates content, which reached its lowest value mean total chlorophyll (35.49 and 36.53 SPAD) and total carbohydrate (18.81 and $20.40 \%$ ) in the first and second seasons, respectively, in plants receiving the highest cadmium concentration $300 \mathrm{mg} / \mathrm{L}$. While, proline content $(1.35$ and $1.39 \mathrm{mg} / \mathrm{g}$ ) were obtained in the plants irrigated with tap water.

The results of leaf chemical analysis Table (6) also showed that tryptophan treatments had clear effect on the leaf chemical analysis. The recorded mean values highest mean total chlorophyll (39.26 and 39.80 SPAD) and total carbohydrate (20.92 and $22.22 \%$ ) in the first and second seasons, respectively, in plants sprayed with tryptophan at $250 \mathrm{mg} / \mathrm{L}$. While, highest proline content (2.01 and $2.04 \mathrm{mg} / \mathrm{g}$ ) were obtained in plants sprayed without tryptophan.

Regarding the interaction between of irrigation using water polluted with cadmium and tryptophan treatments, the data presented in Table (6) showed that the highest total chlorophyll contents (44.05 and 44.42 SPAD) and total carbohydrate (23.59 and $24.80 \%$ ) in the first and second seasons, respectively, were found in leaves of plants irrigated with tap water and sprayed with tryptophan at 250 $\mathrm{mg} / \mathrm{L}$. While, proline content $(2.52$ and $2.50 \mathrm{mg} / \mathrm{g}$ ) were resulted in when the plants were irrigated using the highest cadmium concentration (300 $\mathrm{mg} / \mathrm{L}$ ) without tryptophan treatment.

3.2.2. Cadmium content in leaves and corm (mg/L)

The data resulting from plant parts chemical analysis Table (7) showed that, the cadmium content $(\mathrm{mg} / \mathrm{L})$ in the dried plant parts of Polianthes tuberosa plants was raised steadily with raising the cadmium concentration in the irrigation water. The lowest mean cadmium content in leaves $(0.024$ and $0.029 \mathrm{mg} / \mathrm{L})$ and cadmium content in corm $(0.093$ and $0.109 \mathrm{mg} / \mathrm{L}$ ) in the first and second seasons, respectively, were found in leaves of plants irrigated with tap water, whereas the highest mean values cadmium content in leaves $(0.197$ and $0.216 \mathrm{mg} / \mathrm{L})$ and cadmium content in corm (0.607 and 0.662 $\mathrm{mg} / \mathrm{L}$ ) in the first and second seasons, respectively, was found in plants irrigated with water containing the highest cadmium concentration $300 \mathrm{mg} / \mathrm{L}$.

Concerning the effect of tryptophan treatments on the cadmium content in plant parts, the data recorded in the two seasons Table (7) showed that only one tryptophan treatment $500 \mathrm{mg} / \mathrm{L}$ caused a significant decrease in mean values of cadmium content in leaves $(0.068$ and $0.078 \mathrm{mg} / \mathrm{L})$ and

Table 6: Means of chemical constituents characteristics of Polianthes tuberosa plants as influenced by cadmium (Cd), tryptophan (T) and their combinations $(\mathrm{Cd} \times \mathrm{T})$ in the two seasons of 2018 and 2019.

\begin{tabular}{|c|c|c|c|c|c|c|c|}
\hline \multicolumn{2}{|c|}{ Treatments } & \multicolumn{2}{|c|}{$\begin{array}{c}\text { Chlorophyll content } \\
\text { (SPAD) }\end{array}$} & \multicolumn{2}{|c|}{$\begin{array}{c}\text { Carbohydrates content } \\
(\%)\end{array}$} & \multicolumn{2}{|c|}{$\begin{array}{l}\text { Proline content } \\
(\mathrm{mg} / \mathrm{g} \text { d.w. })\end{array}$} \\
\hline $\begin{array}{l}\text { Cadmium } \\
(\mathrm{mg} / \mathrm{L})\end{array}$ & $\begin{array}{l}\text { Tryptophan } \\
(\mathrm{mg} / \mathrm{L})\end{array}$ & 2018 & 2019 & 2018 & 2019 & 2018 & 2019 \\
\hline \multirow{3}{*}{000} & 0 & 42.05 & 42.41 & 22.48 & 23.68 & 1.40 & 1.43 \\
\hline & 250 & 44.05 & 44.42 & 23.59 & 24.80 & 1.27 & 1.33 \\
\hline & 500 & 43.12 & 43.64 & 23.08 & 24.37 & 1.38 & 1.41 \\
\hline Mean $(\mathrm{Cd})$ & & 43.07 & 43.49 & 23.05 & 24.28 & 1.35 & 1.39 \\
\hline \multirow{3}{*}{100} & 0 & 38.42 & 39.02 & 20.45 & 21.74 & 1.86 & 1.91 \\
\hline & 250 & 40.22 & 40.29 & 21.46 & 22.49 & 1.82 & 1.84 \\
\hline & 500 & 38.98 & 39.20 & 20.77 & 21.89 & 1.83 & 1.85 \\
\hline Mean $(\mathrm{Cd})$ & & 39.20 & 39.50 & 20.89 & 22.04 & 1.83 & 1.86 \\
\hline \multirow{3}{*}{200} & 0 & 35.52 & 36.72 & 18.83 & 20.50 & 2.28 & 2.33 \\
\hline & 250 & 37.23 & 37.91 & 19.79 & 21.16 & 2.23 & 2.29 \\
\hline & 500 & 36.66 & 37.60 & 19.48 & 21.02 & 2.27 & 2.30 \\
\hline Mean $(\mathrm{Cd})$ & & 36.47 & 37.41 & 19.36 & 20.89 & 2.26 & 2.30 \\
\hline \multirow{3}{*}{300} & 0 & 35.43 & 36.46 & 18.78 & 20.36 & 2.52 & 2.50 \\
\hline & 250 & 35.56 & 36.60 & 18.86 & 20.44 & 2.50 & 2.46 \\
\hline & 500 & 35.49 & 36.53 & 18.81 & 20.40 & 2.51 & 2.47 \\
\hline Mean $(\mathrm{Cd})$ & & 35.49 & 36.53 & 18.81 & 20.40 & 2.51 & 2.47 \\
\hline \multirow{3}{*}{ Mean $(\mathrm{T})$} & 0 & 37.85 & 38.65 & 20.13 & 21.57 & 2.01 & 2.04 \\
\hline & 250 & 39.26 & 39.80 & 20.92 & 22.22 & 1.95 & 1.98 \\
\hline & 500 & 38.56 & 39.24 & 20.53 & 21.92 & 1.99 & 2.00 \\
\hline \multirow{3}{*}{ L.S.D. at 0.05} & $\mathrm{Cd}$ & 0.67 & 0.76 & 0.37 & 0.43 & 0.05 & 0.04 \\
\hline & $\mathrm{T}$ & 0.36 & 0.30 & 0.20 & 0.17 & 0.02 & 0.02 \\
\hline & $\mathrm{Cd} * \mathrm{~T}$ & 0.41 & 0.34 & 0.23 & 0.19 & 0.02 & 0.02 \\
\hline
\end{tabular}


Table 7: Means of chemical constituents characteristics of Polianthes tuberosa plants as influenced by cadmium (Cd), tryptophan ( $\mathrm{T})$ and their combinations $(\mathrm{Cd} \times \mathrm{T})$ in the two seasons of 2018 and 2019.

\begin{tabular}{|c|c|c|c|c|c|}
\hline \multicolumn{2}{|l|}{ Treatments } & \multicolumn{2}{|c|}{$\begin{array}{c}\text { Cadmium content in leaves } \\
(\mathrm{mg} / \mathrm{L})\end{array}$} & \multicolumn{2}{|c|}{$\begin{array}{c}\text { Cadmium content in corm } \\
(\mathrm{mg} / \mathrm{L})\end{array}$} \\
\hline $\begin{array}{l}\text { Cadmium } \\
(\mathrm{mg} / \mathrm{L})\end{array}$ & $\begin{array}{l}\text { Tryptophan } \\
(\mathrm{mg} / \mathrm{L})\end{array}$ & 2018 & 2019 & 2018 & 2019 \\
\hline \multirow{3}{*}{000} & 0 & 0.033 & 0.048 & 0.137 & 0.166 \\
\hline & 250 & 0.026 & 0.025 & 0.102 & 0.110 \\
\hline & 500 & 0.013 & 0.016 & 0.041 & 0.051 \\
\hline Mean $(\mathrm{Cd})$ & & 0.024 & 0.029 & 0.093 & 0.109 \\
\hline \multirow{3}{*}{100} & 0 & 0.104 & 0.101 & 0.338 & 0.329 \\
\hline & 250 & 0.063 & 0.066 & 0.217 & 0.228 \\
\hline & 500 & 0.035 & 0.045 & 0.129 & 0.175 \\
\hline Mean $(\mathrm{Cd})$ & & 0.067 & 0.070 & 0.228 & 0.244 \\
\hline \multirow{3}{*}{200} & 0 & 0.130 & 0.139 & 0.414 & 0.439 \\
\hline & 250 & 0.118 & 0.121 & 0.377 & 0.383 \\
\hline & 500 & 0.076 & 0.089 & 0.256 & 0.293 \\
\hline Mean $(\mathrm{Cd})$ & & 0.108 & 0.116 & 0.349 & 0.371 \\
\hline \multirow{3}{*}{300} & 0 & 0.249 & 0.278 & 0.757 & 0.841 \\
\hline & 250 & 0.195 & 0.208 & 0.600 & 0.638 \\
\hline & 500 & 0.148 & 0.163 & 0.466 & 0.508 \\
\hline Mean $(\mathrm{Cd})$ & & 0.197 & 0.216 & 0.607 & 0.662 \\
\hline \multirow{3}{*}{ Mean $(\mathrm{T})$} & 0 & 0.129 & 0.141 & 0.411 & 0.443 \\
\hline & 250 & 0.100 & 0.105 & 0.324 & 0.339 \\
\hline & 500 & 0.068 & 0.078 & 0.223 & 0.256 \\
\hline \multirow{3}{*}{ L.S.D. at 0.05} & $\mathrm{Cd}$ & 0.004 & 0.004 & 0.009 & 0.014 \\
\hline & $\mathrm{T}$ & 0.001 & 0.003 & 0.005 & 0.008 \\
\hline & $\mathrm{Cd} * \mathrm{~T}$ & 0.006 & 0.003 & 0.006 & 0.007 \\
\hline
\end{tabular}

cadmium content in corm $(0.223$ and $0.256 \mathrm{mg} / \mathrm{L})$ in the first and second seasons, respectively, compared to that of control plants had the highest cadmium content in leaves $(0.129$ and $0.141 \mathrm{mg} / \mathrm{L})$ and cadmium content in corm $(0.607$ and $0.662 \mathrm{mg} / \mathrm{L})$ in the first and second seasons, respectively.

Concerning the interaction between of irrigation using water contaminated with cadmium and tryptophan treatments on the cadmium content in plant parts. The results in Table (7) showed that the lowest mean values of cadmium content in leaves $(0.013$ and $0.016 \mathrm{mg} / \mathrm{L})$ and cadmium content in corm $(0.041$ and $0.051 \mathrm{mg} / \mathrm{L})$ in the first and second seasons, respectively, were obtained in the plant parts irrigated with tap water and sprayed with tryptophan at $500 \mathrm{mg} / \mathrm{L}$. On the other hand, the highest cadmium content was obtained in the plant parts of irrigated with cadmium water at $300 \mathrm{mg} / \mathrm{L}$ and receiving no tryptophan treatment in leaves $(0.249$ and $0.278 \mathrm{mg} / \mathrm{L})$ and cadmium content in corm $(0.757$ and $0.841 \mathrm{mg} / \mathrm{L})$ in the first and second seasons, respectively.

\subsection{Transfer factor (TF) of heavy metals}

Transfer factor (TF) indicates the efficiency of plants to transfer metals from root to the aerial parts.

\subsubsection{Cadmium content in soil samples $(\mathrm{mg} / \mathrm{L})$}

Data in Table (8) showed that the lowest average of cadmium content was observed in soil cultured by untreated plants, while the highest average of cadmium content was observed in soil after the treatment $300 \mathrm{mg} / \mathrm{L}$ cadmium and $0 \mathrm{mg} / \mathrm{L}$ tryptophan.

\subsubsection{Transfer factor to leaves and corm}

From the data presented in Table (9), it can be seen that the transfer factor in the dried plant parts of Polianthes tuberosa plants was increased steadily with raising the cadmium concentration in the irrigation water. Accordingly, the highest cadmium value in leaves (1.554 and 1.538) and in corm (4.782 and 4.705) was found in plants irrigated with water containing cadmium concentration $300 \mathrm{mg} / \mathrm{L}$, whereas the lowest value in leaves $(0.293$ and $0.307)$ and in corm (1.073 and 1.124) was found in plants irrigated with tap water (control). 
The results in Table (9) also showed that the transfer factor in the dried plant parts was reduced steadily with raising tryptophan concentration. Accordingly, the highest cadmium value in leaves (1.252 and 1.228) and in corm (4.048 and 3.873) was recorded in the control plants, whereas plants sprayed with the highest tryptophan concentration $500 \mathrm{mg} / \mathrm{L}$ had the lowest cadmium value in leaves (0.486 and 0.498$)$ and in corm (1.600 and 1.642) in the first and second seasons, respectively.

Table 8: Average of cadmium content in soil samples as influenced by cadmium concentrations in water irrigation and foliar application of tryptophanon Polianthes tuberosa in the two seasons of 2018 and 2019.

\begin{tabular}{|c|c|c|c|c|c|}
\hline \multicolumn{2}{|c|}{ Treatments } & \multicolumn{4}{|c|}{$\begin{array}{l}\text { Cadmium content in soil } \\
(\mathrm{mg} / \mathrm{L})\end{array}$} \\
\hline \multirow{2}{*}{$\begin{array}{l}\text { Cadmium } \\
(\mathrm{mg} / \mathrm{L})\end{array}$} & \multirow{2}{*}{$\begin{array}{l}\text { Tryptophan } \\
\text { (mg/L) }\end{array}$} & \multicolumn{2}{|c|}{2018} & \multicolumn{2}{|c|}{2019} \\
\hline & & Before & After & Before & After \\
\hline \multirow{3}{*}{0} & 0 & 0.033 & 0.068 & 0.042 & 0.086 \\
\hline & 250 & 0.047 & 0.095 & 0.054 & 0.109 \\
\hline & 500 & 0.050 & 0.107 & 0.057 & 0.117 \\
\hline \multirow{3}{*}{100} & 0 & 0.045 & 0.092 & 0.052 & 0.107 \\
\hline & 250 & 0.053 & 0.109 & 0.063 & 0.128 \\
\hline & 500 & 0.063 & 0.128 & 0.074 & 0.147 \\
\hline \multirow{3}{*}{200} & 0 & 0.051 & 0.104 & 0.058 & 0.115 \\
\hline & 250 & 0.060 & 0.123 & 0.067 & 0.136 \\
\hline & 500 & 0.069 & 0.139 & 0.076 & 0.154 \\
\hline \multirow{3}{*}{300} & 0 & 0.057 & 0.116 & 0.064 & 0.126 \\
\hline & 250 & 0.064 & 0.129 & 0.071 & 0.145 \\
\hline & 500 & 0.073 & 0.147 & 0.081 & 0.167 \\
\hline
\end{tabular}

Table 9: Means of transfer factor to leaves, stem and roots of Polianthes tuberosa plants as influenced by cadmium $(\mathrm{Cd})$, tryptophan $(\mathrm{T})$ and their combinations $(\mathrm{Cd} \times \mathrm{T})$ in the two seasons of 2018 and 2019.

\begin{tabular}{|c|c|c|c|c|c|}
\hline \multicolumn{2}{|c|}{ Treatments } & \multicolumn{2}{|c|}{$\begin{array}{c}\text { Transfer factor to leaves } \\
\text { (TFL) }\end{array}$} & \multicolumn{2}{|c|}{$\begin{array}{c}\text { Transfer factor to corm } \\
\text { (TFS) }\end{array}$} \\
\hline $\begin{array}{l}\text { Cadmium } \\
(\mathrm{mg} / \mathrm{L})\end{array}$ & $\begin{array}{l}\text { Tryptophan } \\
(\mathrm{mg} / \mathrm{L})\end{array}$ & 2018 & 2019 & 2018 & 2019 \\
\hline \multirow{3}{*}{000} & 0 & 0.485 & 0.558 & 2.014 & 1.930 \\
\hline & 250 & 0.273 & 0.229 & 1.073 & 1.009 \\
\hline & 500 & 0.121 & 0.136 & 0.383 & 0.435 \\
\hline Mean $(\mathrm{Cd})$ & & 0.293 & 0.307 & 1.156 & 1.124 \\
\hline \multirow{3}{*}{100} & 0 & 1.130 & 0.943 & 3.673 & 3.074 \\
\hline & 250 & 0.577 & 0.515 & 1.990 & 1.781 \\
\hline & 500 & 0.273 & 0.306 & 1.007 & 1.190 \\
\hline Mean $(\mathrm{Cd})$ & & 0.660 & 0.588 & 2.223 & 2.015 \\
\hline \multirow{3}{*}{200} & 0 & 1.250 & 1.208 & 3.980 & 3.817 \\
\hline & 250 & 0.959 & 0.889 & 3.065 & 2.816 \\
\hline & 500 & 0.546 & 0.577 & 1.841 & 1.902 \\
\hline Mean $(\mathrm{Cd})$ & & 0.918 & 0.891 & 2.962 & 2.845 \\
\hline \multirow{3}{*}{300} & 0 & 2.146 & 2.206 & 6.525 & 6.674 \\
\hline & 250 & 1.511 & 1.434 & 4.651 & 4.400 \\
\hline & 500 & 1.006 & 0.976 & 3.170 & 3.041 \\
\hline Mean $(\mathrm{Cd})$ & & 1.554 & 1.538 & 4.782 & 4.705 \\
\hline \multirow{3}{*}{ Mean $(\mathrm{T})$} & 0 & 1.252 & 1.228 & 4.048 & 3.873 \\
\hline & 250 & 0.830 & 0.766 & 2.694 & 2.501 \\
\hline & 500 & 0.486 & 0.498 & 1.600 & 1.642 \\
\hline
\end{tabular}




\section{DISCUSSION}

This study revealed that at high heavy-metal concentrations, the plant height was significantly reduced, and the biomass was decreased. The root growth was more sensitive than other parameters, as roots rapidly absorbed water and had higher accumulations of heavy metal elements. The results presented by this study were in agreement with earlier reports on other plants, such as aquatic plant Wolffia arrhiza (Piotrowska et al., 2010), barley Hordeum vulgare (Tiryakioglu et al., 2006) and Typha angustifolia (Bah et al., 2011) and Jatropha curcas (El-Shanhorey and Emam, 2016). Cadmium has been shown to cause many morphological, physiological and biochemical changes in plants, such as growth inhibition, and water imbalance (Benavides et al., 2005).

The physiological responses, photosynthetic function, can be ascribed to the different effects of physico-chemical properties of heavy metals on the integrity and function of the photochemical apparatus of plant seedling fronds, as well as the impact on the chlorophyll concentrations in the leaves. The photosynthesis rate, $\mathrm{CO}_{2}$ assimilation rate, and stomatal conductance in response to cadmium heavy metal have been well documented (Chen et al., 2012). The maintenance of an intercellular $\mathrm{CO}_{2}$ concentration is concomitant with the leaf $\mathrm{CO}_{2}$ assimilation rate and reflected photosynthesis function of seedling in the different heavy metal-spiked soils. The chlorophyll and carotenoid contents played a central role in the energy manifestation of green plant. Any significant alteration of their contents possibly resulted in a marked effect on the entire metabolism of the plant (Piotrowska et al., 2010). In this study, cadmium resulted in a significant reduction in the chlorophyll contents, possibly due to the inhibition of chlorophyll biosynthesis or a breakdown of pigments and their precursors (Agrawal and Mishra, 2009). cadmium might replace the central $\mathrm{Mg}$ from chlorophyll molecules and thereby reduce the photosynthetic light-harvesting ability of plant (Agrawal and Mishra, 2009).

In the present study, cadmium exposure significantly decreased photosynthetic pigments concentrations in comparison with control plants. Reduction in photosynthetic pigments by excess cadmium has been reported by some author i.e. Abdel-Latif (2008). Decreased chlorophyll content associated with heavy metal stress may be the result of inhibition of the enzymes responsible for chlorophyll biosynthesis. In addition, Cadmiuminduced decrement in chlorophyll content was attributed to impairment in the supply of magnesium and iron to the leaves (Greger and Ogren, 1991). Alternatively, cadmium may substitute magnesium in chlorophyll molecules (Kupper et al., 1998).
Proline, an amino acid is well known to get accumulated in wide variety of organisms ranging from bacteria to higher plants on exposure to abiotic stress (Saradhi et al., 1993). Plants have been shown proline accumulation under environmental stress (Ahmad and Jhon, 2005; Ahmad et al., 2006; Ahmad et al., 2008). It has been often suggested that proline accumulation may contribute to osmotic adjustment at the cellular level and enzyme protection stabilizing the structure of macromolecules and organelles. Increase in proline content may be either due to de novo synthesis or decreased degredation or both (Kasai et al., 1998). Proline accumulation in shoots of B. juncea, Triticum aestivum and Vigna radiata in response to $\mathrm{Cd}^{2+}$ toxicity has been demonstrated by Dhir et al., (2004). Similar results of increasing proline content by $\mathrm{Cd}^{2+}$ was also reported by Zengin and Munzuroglu, (2006) in sunflower.

Concerning treatments, at a preliminary stage, one should note that the transfer factor (TF) of most treatments is lower than one for cadmium; which means that the physiological need of the plant for this element is rather limited. Translocation from roots to shoots via a number of physiological processes, including metal unloading into root xylem cells, long-distance carrying from the xylem to the shoots and metal reabsorption, by leaf mesophyll cells, from the xylem stream. Once the cadmium has been unloaded into the xylem vessels, the metals are carried to the shoots by the transpiration stream (Blaylock and Huang, 2000).

The role of tryptophan is well known: it has an indirect role on the growth via its influence on auxin synthesis. Phillips, (1971) reported that alternative routes of IAA synthesis exist in plants, all starting from tryptophan. Thus, when tryptophan was supplied to some plant tissues IAA was formed. Moursy et al., (1988) established callus lines of Datura stramonium L. and found that phenylalanine and ornithine increased both fresh and dry weights compared with the control. Moreover, there have been reports that foliar application of amino acids (Lysine, ornithine, salicylic acid and tryptophan) enhanced the vegetative growth and chemical constituents (Talaat and Youssef, 2002) on basil plants, (Talaat, 2005) on Pelargonium graveolens L. and (Talaat et al., 2005) on Catharanthus roseus L.

For the effect of tryptophan it is observed that there is a significant increase in all vegetative parameters, chlorophyll content, carbohydrate percentage, significant decrease in cadmium content in leaves. This may be due to that application of tryptophan with any of the concentrations of cadmium led to a statistically decrease in the uptake of cadmium. This decrease in uptake of cadmium in the presence of tryptophan resulted in the formation of citric acid-cadmium complexes that inhibited the uptake (Chen et al., 2003). The decrease in 
cadmium uptake helped to overcome the negative effects of cadmium on the previous studied parameters. These results are in agreement with those mentioned by (Talebi et al., 2014) on Gazania plants and (Jaafari and Hadavi, 2012) on Ocimum basilicum L. In addition to, we can use Senecio cineraria plants as cadmium phytoremediation and if we want to use Senecio cineraria as an ornamental plant and the irrigation water is contaminated with cadmium we can spray the plants to overcome the negative effect of cadmium (ElShanhorey and EL-Sayed, 2017).

\section{CONCLUSIONS}

The concentrations of heavy metals increase in the environment from year to year. Therefore decontamination of heavy metal-contaminated water and soils is very important for maintenance of environmental health and ecological restoration. Phytoremediation is a new cleanup concept that involves the use of plants to clean or stabilize contaminated environments. Phytoremediation of metals is the most effective plant-based method to remove pollutants from contaminated areas. This green technology can be applied to remediate the polluted soils without creating any destructive effect of soil structure. Some specific plants have been proven to have noticeable potential to absorb toxic heavy metals.

Phytoremediation of contaminated water and soil with heavy metals using non-edible plant like Polianthes tuberosa offers an environmental friendly and cost-effective method for remediating the polluted soil. The Polianthes tuberosa was found to be able to efficiently remove the heavy metals such as cadmium.

\section{REFERENCES}

Abdel-Latif Amani. (2008) Cadmium changes in pigment content, ion uptake, praline content and phosphoenolpyruvate carboxylase activity in Triticum aestivum seedlings. Aust. J. of Bascic and applied Sciences, 2(1), 57-62.

Agrawal S.B. and S. Mishra (2009). Effects of supplemental ultraviolet-B and cadmium on growth, antioxidants and yield of PisumsativumL. Ecotoxicol. Environ. Saf.,72: 610-618.

Ahmad P. and Jhon R. (2005). Effect of Salt stress on growth and biochemical parameters of Pisum sativum L. Arch. Agro. Soil Sci. 51, 665672.

Ahmad P., Jhon R., Sarwat M. and Umar S. (2008). Responses of proline, lipid peroxidation and antioxidative enzymes in two varieties of Pisum sativum L. under salt stress. Int. J. Plant Production. 2: 353-366.
Ahmad P., Sharma S. and Srivastava P.S. (2006). Differential physio-biochemical responses of high yielding varieties of Mulberry (Morus alba) under alkalinity (Na2CO3) stress in vitro. Physiol. Mol. Biol. Plants 12, 59-66.

Bah A.M., Dai H., Zhao J., Sun H., Cao F., Zhang G. and Wu F. (2011). Effects of cadmium, chromium and lead on growth, metal uptake and antioxidative capacity in Typha angustifolia. Biol. Trace Elem. Res., 142: 77-92.

Bates L.S., Waldern R.P. and Teare L. D. (1973). Rapid determination of free proline under water stress studies. Plant and Soil, 39: 205-207.

Benavides M.P., Gallego S.M. and Tomaro M.L. (2005). Cadmium toxicity in plants. Braz. J. Plant Physiol., 17, 21-34.

Blaylock M. J. and Huang J.W. (2000). Phytoextraction of metals. Phytoremediation of toxic metals: using plants to clean up the environment. Eds., Raskin, I. and B.D. Ensley. John Wiley and Sons, Inc, Toronto, p. 303.

Chen L., Han Y., Jiang H., Korpelainen H. and Li C. (2012). Nitrogen nutrient status induces sexual differences in responses to cadmium in Populusyunnanensis. J. Exp. Bot., 62: 5037-5050.

Chen Y., Shen Z., Li X. (2004). The use of vetiver grass (Vetiveria zizanioides) in the phytoremediation of soils contaminated with heavy metals. Applied Geochemistry 19: 15531565.

Chen Y.X., Lin Q., Luo Y.M., He Y.F., Zhen S.J., $\mathrm{Yu}$ Y.L., Tianand G.M. and Wong M.H. (2003). The role of citric acid on the phytoremediation of heavy metal contaminated soil. Chemosphere, 50: 507-811.

Dhir B., Sharmila P. and Saradhi P.P. (2004). Hydrophytes lack potential to exhibit cadmium stress induced enhancement in lipid peroxidation and accumulation of proline. Aquatic Toxicol. 66, 141-147.

Dubios M., Gilles K., Hamlton J., Rebers P. and Smith F. (1956). Colourimetric method for determination of sugars and related substances. Analytical Chemistry, 28(3): 350- 356.

El-Bassiouny H. M. (2005). Physiological responses of wheat to salinity alleviation by nicotinamide and tryptophan. International Journal of Agriculture and Biology, 7, 654-660.

El-Shanhorey N.A. and Emam K.A. (2016). Response of Jatropha curcas plants to foliar applied ascorbic acid for decreasing the harmful effect of cadmium pollution in the irrigation water. Alex. J. Agric. Sci. Alex.Univ., 61(3): 221-235. 
El-Shanhorey N.A. and EL-Sayed S.G. (2017). The Use of Senecio cineraria Plants Sprayed with Citric Acid for Cadmium Pollution Phytoremediation. Alexandria Science Exchange Journal, 38 (2): 343-355.

Greger M. and Ogren H. (1991). Direct and indirect effects of $\mathrm{Cd}$ on photosynthesis in sugar beet (Beta vulgaris). Physiol. Plant., 83, 129-135.

Jaafari N. and Hadavi E. (2012). "Growth and essential oil yield of Basil (Ocimum basilicum L.) as affected by foliar spray of citric acid and salicylic acid," Zeitschrift fur Arznei- und Gewurzplanzen, 17 (2): 80-83.

Jackson N. L. (1958). Soil Chemical Analysis.Constable. Ltd. Co., London, 498 p.

Kasai Y., Kato M., Aoyama J. and Hyodo H. (1998). Ethylene production and increase in 1aminocyclopropane-1-carboxylate oxidase activity during senescence of broccoli florets. Acta Hort. 464, 153-157.

Koller H.R. (1972). Leaf area, leaf weight relationship in the soybean canopy. Crop Sci., 12: 180-183.

Kupper H., Kupper F. and Spiller M. (1998). In situ detection of heavy metals substituted chlorophylls in water plants. Photosynthesis Res., 58, 123-133.

Lindsay W.L. and Norvell W.A. (1978). Development of a DTPA soil test for zinc, iron, manganese and copper. Soil Sci. Soc. Am. J., 42: 421-428.

Mashiguchi K., Tatsuya T., Sugawara S., Kawaide H., Natsume M., Hanadaa A. and Kasahara H. (2011). The main auxin biosynthesis pathway in Arabidopsis. Proceedings of the National Academy of Science (Early ed., pp. 1-6).

Moursy H.A., Hussein S.M. and El-Bahar K.M. (1988). Effect of some alkaloid precursors on the growth and alkaliod production of Datura stramonium L. cultured in vitro. Egypt. J. Bot., 31: $153-165$.

Phillips L.D.J. (1971). Introduction to the Biochemistry and Physiology of Plant Growth Hormones. Mc. Graw-Hill Book Co.

Piotrowska A., Bajguz A., Godlewska-Zylkiewicz B. and Zambrzycka E. (2010). Changes in growth, biochemical components, and antioxidant activity in aquatic plant Wolffiaarrhiza(Lemnaceae) exposed to cadmium and lead. Arch. Environ. Contam.Toxicol., 58: 594-604.

Piper O.S. (1947). Soil and plant Analysis. Adelaite University, Adelaide, Australia , 258-275.

Ramaih S., Geudira M., and Paulsen G. M. (2003). Relationship of indoleacetic acid and tryptophan dormancy and pre-harvest sprouting of wheat. Funct. Plant Biology, vol. 30: 939945.
Saradhi P., Alia P. and Vani B. (1993). Inhibition of mitochondrial electron transport is the prime cause behind proline accumulation during mineral deficiency in Oryza sativa. Plant Soil 155/156, 465-468.

SAS Institute (2002). SAS User Guide and Program 20 Version 9.0.38. Cary, North Carolina, USA.

Satoko S., Shojiro H., Yusuke J., Atsushi H., Takeshi N. and Yuji K. (2009). Biochemical analyses of indole-3-acetaldoxime-dependent auxin biosynthesis in Arabidopsis. Proceedings of the National Academy of Science, 106, 54305435.

Snedecor G. W. and Cochran W. (1989). Statistical Methods, $8^{\text {th }}$ ed. Edition, Iowa State University Press. Ames. Iowa. USA.

Talaat I.M. (2005). Physiological effect of salicylic acid and tryptophan on Pelargonium graveolens L. Egypt. J. Appl. Sci., 20: 751-760.

Talaat I.M. and A.A. Youssef (2002). The role of the amino acids lysine and ornithine in growth and chemical constituents of basil plants. Egypt. J. Appl. Sci., 17: 83-95.

Talaat I.M., Karima M. and Gamal-El-Din K.M. (2005). Physiological effect of putrescine and heat hardening on Nigellia sativa L. plants. Intl. J. Agric. Biol., 3: 358-362.

Talebi M., Hadavi E. and Jaafari N. (2014). Foliar Sprays of Citric Acid and Malic Acid Modify Growth, Flowering, and Root to Shoot Ratio of Gazania (Gazania rigens L.): A Comparative Analysis by ANOVA and Structural Equations Modeling. Adv. Agric. Article ID, 147278: 1-6.

Tiryakioglu M., Eker S., Ozkutlu F., Husted S. and Cakmak I. (2006). Antioxidant defense system and cadmium uptake in barley genotypes differing in cadmium tolerance. J. Trace Elem. Med. Biol., 20: 181-189.

Trueblood E. W. E. (1973). The tuberose (Polianthes tuberose L.). Economic Botany, 27, 157.

Won C. (2011). Conversion of tryptophan to indole3-acetic acid by tryptophan aminotransferases of Arabidopsis and yuccas in arabidopsis. Proceedings of the National Academy of Science, 108, 18518-18523.

Wyszkowska J. (1999). Modification of faba bean chemical composition caused by precursors of plant growth regulators \& soil microorganism. Effect of L-tryptophan and beta-indolyl acitic acid. Biuletyn-naukowy, 5, 56-63.

Yadava U. (1986). A rapid and nondestructive method to determine chlorophyll in intact leaves. Hort. Sci., 21(6): 1449-1450.

Zengin F.K., Munzuroglu O. (2006). Toxic effects of cadmium $\left(\mathrm{Cd}^{++}\right)$on metabolism of sunflower (Helianthus annuus L.) seedlings. Acta Agricul. Scand., Sect. B, Plant Soil Sci. 56, 224-229. 


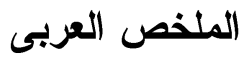

تأثير الرش بالتربتوفان على نباتات التبروز لتقليل الأثر الضار لبعض التلوث بالمعادن الثقيلة فى ماء الرى. (أ) تأثير معاملات الكادميوم.

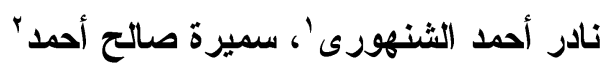

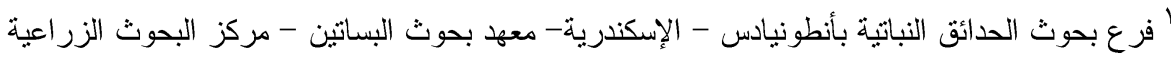

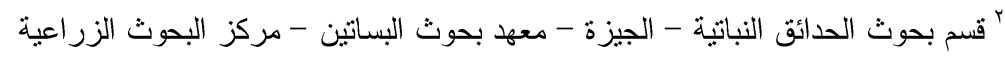

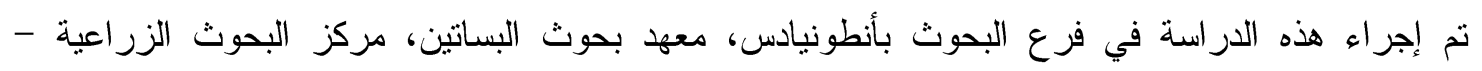

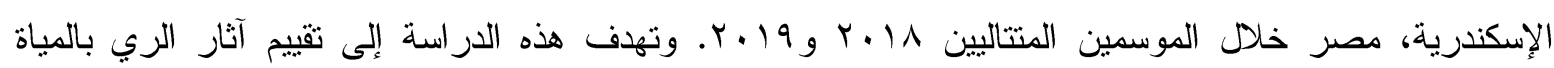

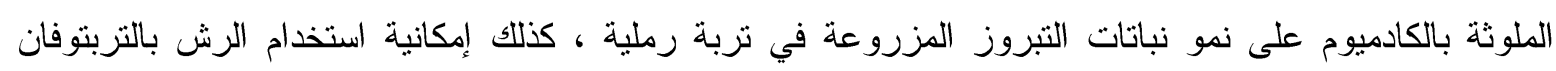

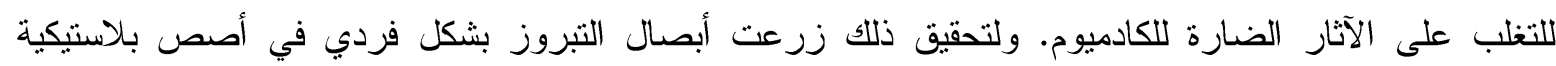

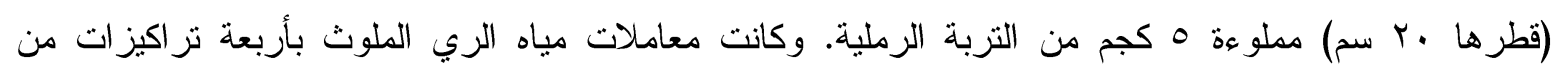

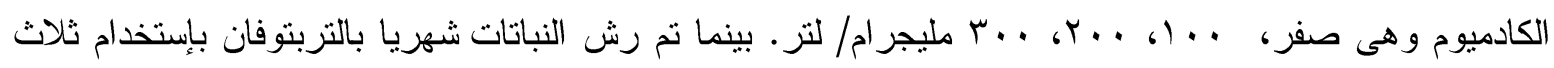

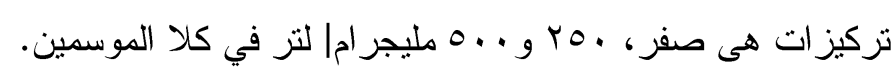

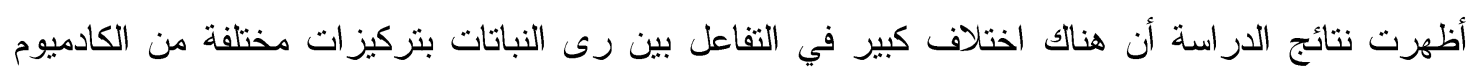

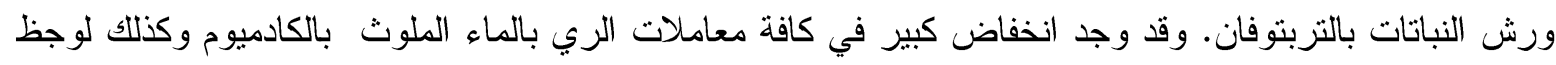

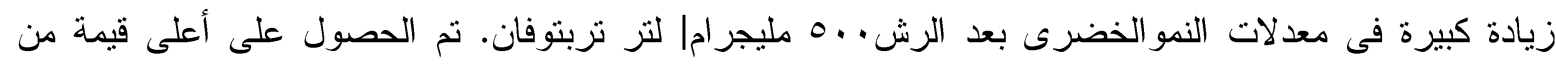

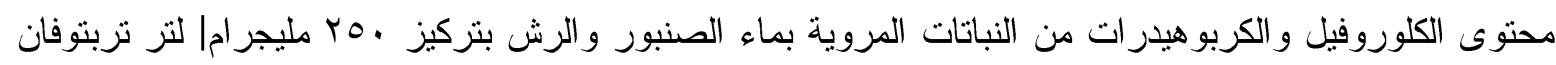

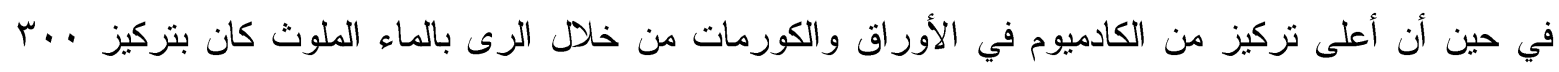

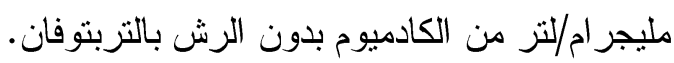

